\title{
CURRENT STATUS OF COHE 100/2000 SCHOLARSHIP HOLDERS: EXPERIENCE OF PHD STUDENTS AT DOKUZ EYLUL UNIVERSITY GRADUATE SCHOOL OF HEALTH SCIENCES
}

\author{
Naz KANIT'1 , Nazli Ecem DAL ${ }^{1}$, Ufkay KARABAY ${ }^{1}$, Gamze TUNA ${ }^{1}$, \\ Erdener OZER ${ }^{1,2}$, Gul Huray ISLEKEL ${ }^{1,3}$
}

\footnotetext{
${ }^{1}$ Dokuz Eylul University Graduate School of Health Sciences, Molecular Medicine Department, Izmir/TURKEY

2 Dokuz Eylul University Faculty of Medicine, Surgery Medicine, Department of Medical Pathology, Izmir/TURKEY

${ }^{3}$ Dokuz Eylul University Faculty of Medicine, Basic Medical Sciences, Department of Medical Biochemistry, Izmir/TURKEY
}

Address for Correspondence: Naz KANIT, E-mail: nazkanit@gmail.com Received: 05.01.2021; Accepted: 20.05.2021; Available Online Date: 27.05.2021

(C) Copyright 2021 by Dokuz Eylül University, Institute of Health Sciences - Available online at https://dergipark.org.tr/en/pub/jbachs

Cite this article as: Kanit N, Dal NE, Karabay U, Tuna G, Ozer E, Islekel GH Current Status Of Cohe 100/2000 Scholarship Holders: Experience of Phd Students At Dokuz Eylul University Graduate School Of Health Sciences J Basic Clin Health Sci 2021; 2: 148-155.

\section{ABSTRACT}

Objective: Turkey's Council of Higher Education (CoHE) has started a funding program (CoHE 100/2000 Scholarship Program) since the Spring semester of 2017 to support selected PhD students throughout Turkey. However, this funding program has some fundamental contradictions with the regulations of both Dokuz Eylul University Graduate School of Health Sciences (DEU-GSHS) and the requirements of ORPHEUS (Organization of Education in Biomedicine and Health Sciences in the European System) label awarded to DEU-GSHS in 2015. Consequently, the contradictions create a relatively stressful PhD process for these selected students. The aim of this study was to understand DEU-GSHS CoHE 100/2000 scholarship holders' opinions and expectations, as well as the conflicts on regulations they come across during their studies.

Methods: Twenty-one CoHE 100/2000 students of DEU-GSHS filled out a survey that consists of 17 statements alongside their opinions on the subject.

Results: Most students were aware of the conflicts among the institutional regulations, creating a stressful PhD environment for most of the participants. We believe that assignment of a student representative to be in charge of conveying those problems to authorities would be the best way to solve most of the issues mentioned throughout the article. Additionally, amelioration of career counselling, organization of regular meetings and providing the flexibility to extend the scholarship duration could improve PhD students' current conditions.

Conclusion: This study reveals the urgent need of harmonizing the regulations of all the associated institutions involved in the PhD process of CoHE 100/2000 scholarship holders.

Keywords: PhD, CoHE 100/2000, Scholarship 


\section{INTRODUCTION}

Turkey's Council of Higher Education (CoHE) has launched the "CoHE 100/2000 PhD Scholarship Program" in 100 chosen thematic areas as a way to train strong generations for the upcoming ten years in accordance with Turkish Government's development plan. With the aim of raising "qualified work force", $\mathrm{CoHE}$ launched this program on 2017. Since then, more than 4250 students from 75 universities all over the country have been awarded with the scholarship and the number of students is growing over time. $(1,2,3,4,5)$

CoHE 100/2000 scholarship provides PhD students with a reasonable amount of support for a maximum of eight semesters, letting them focus implicitly on their research areas during this period, fulfilling a whole $\mathrm{PhD}$ experience. This program supports $\mathrm{PhD}$ students studying in a wide variety of disciplines; including micro and nanotechnology, organic agriculture, social media studies, molecular pathology, immigration studies and many others. By 2018, seventy-five universities across Turkey got involved in the program with different thematic areas. Dokuz Eylül University (DEU) provides CoHE $100 / 2000$ scholarship for 128 PhD students, making it the third university with the most students obtaining the bursary by April, 2018. Twenty-eight of these students are enrolled in various programs in Dokuz Eylül University Graduate School of Health Sciences (GSHS) (1).

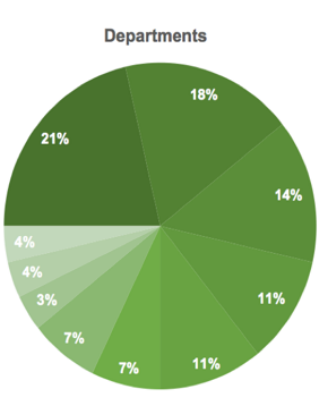

- basic oncology (6)

- molecular medicine (5)

-neuroscience (4)

-medical biology and genetics (3)

- biomechanics (3)

-microbiology (2)

-medical physics (2)

- translational oncology (1)

"biochemistry (1)

= medical parasitology (1)

Figure.1: Distribution of departments and thematic areas of the CoHE 100/2000 scholarship holders in DEU-GSHS $(n=28)$
According to the CoHE regulations, each scholarship holder should submit their thesis proposal on one of the chosen thematic areas by the end of the first semester, since the program aims to expand the time a PhD student spends on their thesis which will lead to a better research outcome.

On the other hand, CoHE 100/2000 scholarship holders in Dokuz Eylül University GSHS are subject to additional responsibilities in line with the ORPHEUS label which was awarded to GSHS in 2015. ORPHEUS (short for Organization of Education in Biomedicine and Health Sciences in the European System) is an association which aims to advance and spread the best practice in $\mathrm{PhD}$ programs in health sciences (6). For a PhD student to obtain a PhD degree with ORPHEUS label, there are several requirements, some of which concerning the publications before graduation are as follows:

To take the PhD proficiency exam, each student should present at least one research article/review/case study (national or international refereed journal) which should be related to the thesis subject and where they are the first or the second author. In addition, one poster/oral presentation should be presented. $(7,8)$

To defense the PhD thesis, each student should present three research articles, two of which should be published or accepted to be published whereas the third one can be presented as a manuscript. All these three research articles are expected to be related to the thesis subject and be submitted to national or international refereed journals. $(7,8)$

The above-mentioned ORPHEUS requirements obviously guide students to a successful $\mathrm{PhD}$ thesis and overall a productive $\mathrm{PhD}$ process. However, from the point of DEU-GSHS CoHE 100/2000 PhD students, these requirements might be perceived as hard to fulfill, considering the four-year limit of CoHE $100 / 2000$ bursary. In addition to ORPHEUS requirements, GSHS has certain regulations (Table 1) some of which are not fully in accordance with CoHE 100/2000 process. The main conflict between GSHS guidelines and CoHE 100/2000 is as follows: GSHS guidelines state that $\mathrm{PhD}$ students can only submit their thesis proposals after they successfully take the proficiency exam. This creates a delay for the PhD Student Project grant application to DEU Scientific Research Project Department (BAP) who financially supports the research projects, since the application to this grant requires an accepted thesis proposal (9). Regarding the eight-semester period 
restriction for CoHE 100/2000 scholarship holders, these limiting procedures inevitably hampers a successful $\mathrm{PhD}$ thesis process in the anticipated time frame.

In practice, we believe that there is a lack of harmonization between DEU-GSHS regulations, ORPHEUS and CoHE 100/2000 Scholarship Program, which leads to a stressful environment for DEU-GSHS CoHE 100/2000 scholarship holders. In the light of these observations we have conducted this study to reveal the current stand point from their perspective.

Table 1. Some of the main requirements to be fulfilled by DEU-GSHS CoHE 100/2000 students.

\begin{tabular}{|c|c|}
\hline $1^{\text {st }}$ semester & $\begin{array}{l}\text { Submission of Thesis } \\
\text { Proposal for CoHE 100/2000 } \\
\text { Scholarship Program }\end{array}$ \\
\hline End of $1^{\text {st }}$ semester & $\begin{array}{l}\text { Obtaining and submitting the } \\
\text { Ethics Committee Approval of } \\
\text { thesis project to the Institute }\end{array}$ \\
\hline $\begin{array}{l}\text { Before PhD } \\
\text { Proficiency }\end{array}$ & $\begin{array}{l}\text { Submission of one article and } \\
\text { one poster/oral presentation } \\
\text { related to the thesis subject }\end{array}$ \\
\hline $\begin{array}{l}\text { Between } 4^{\text {th }} \text { and } 5^{\text {th }} \\
\text { semesters }\end{array}$ & PhD Proficiency Exam \\
\hline $\begin{array}{l}\text { After PhD } \\
\text { Proficiency }\end{array}$ & $\begin{array}{l}\text { Assignation of Advisory } \\
\text { Committee and submission of } \\
\text { the thesis proposal to the } \\
\text { institute }\end{array}$ \\
\hline $8^{\text {th }}$ semester & $\begin{array}{l}\text { Defense of thesis and } \\
\text { submission of three articles as } \\
\text { defined by ORPHEUS } \\
\text { regulations. }\end{array}$ \\
\hline \multicolumn{2}{|c|}{$\begin{array}{l}\text { DEU: Dokuz Eylul University, GSHS: Graduate School of Health } \\
\text { Sciences; CoHE: Council of Higher Education; ORPHEUS: } \\
\text { Organization of Education in Biomedicine and Health Sciences in } \\
\text { the European System }\end{array}$} \\
\hline
\end{tabular}

\section{METHODS}

This study was conducted between June - September 2018 in Dokuz Eylül University, Izmir. DEU-GSHS CoHE 100/2000 scholarship holders who have been pursuing their $\mathrm{PhD}$ for at least one semester $(n=28)$ were included in the study. Distribution of departments and thematic areas of all the mentioned students were analyzed. Additionally, a survey was prepared to reveal the students' knowledge, perception and expectations on the current educational issues and was sent to all of these students via e-mail. Twenty one out of 28 students filled out the survey completely. The survey included 17 statements to be graded from 1 to 5 (1: Strongly disagree, 2: Disagree, 3: Neutral, 4: Agree, 5: Strongly agree). In order to simplify the interpretation of results, statements were grouped into four main topics, namely, institutional regulations (Statements 1-5), institutional resources (Statements 6-8), DEU CoHE 100/2000 Coordination Unit (Statements 9-13) and Coordination of CoHE 100/2000 Scholarship Program and DEU-GSHS (Statements 14-17).

The survey also contained five open ended questions concerning the information on students' age, gender, department, thematic area and their current semester. The age variable was statistically analyzed by IBM SPSS Statistics v.23 software. Lastly, the survey ended with a section where the students could write down their additional comments, expectations and opinions on the subject. Seven students included their opinions at the end of the survey.

\section{RESULTS}

The distribution of departments and thematic areas of the students supported with CoHE 100/2000 scholarship for at least one semester in DEU-GSHS $(n=28)$ are displayed in Figure 1. As for demographics, $71 \%$ of students who had filled the survey $(n=21)$ were female, and $29 \%$ were male. Analysis of age distribution of the same students $(n=21)$ showed that median age was 29 (minimum: 23, maximum: 34 , mean: 29,24 , standard deviation: $2,755)$. The statements in the survey and the percentage distribution of the results are shown in Table 2.

\section{DISCUSSION}

This article aims to reveal the challenges of DEUGSHS' CoHE 100/2000 scholarship holders in terms of some incompatible regulations of CoHE, GSHS and ORPHEUS, with the aid of a comprehensive survey. Answers to this survey are discussed below in detail to present the students' perspective on the regulations, as well as their expectations from $\mathrm{CoHE}$ 100/2000 Scholarship Program.

\section{Institutional Regulations}

In order to assess students' knowledge and view on the institutional regulations, first five statements of the survey were evaluated. Most of the students agree or strongly agree that, they are aware of the institutional regulations $(71,4 \%$, Statement 1$)$; they have to succeed the PhD proficiency exam to submit their thesis proposals $(90,5 \%$, Statement 3$)$; and they know how and when to apply to the $\mathrm{PhD}$ project grant $(71,5 \%$, Statement 4$)$. Less than half of the students think that the institute provides them with enough information on administrative issues (Statement 2). Finally, the results of statement 5 reveals nearly $90 \%$ 
Table 2: Statements in the survey and distribution of results $(n=21)$

\begin{tabular}{|c|c|c|c|c|c|c|}
\hline \multirow{2}{*}{\multicolumn{2}{|c|}{ Statements }} & \multicolumn{5}{|c|}{ Answers ${ }^{*}(n=21)$} \\
\hline & & SD (\%) & D (\%) & $\mathbf{N}(\%)$ & $A(\%)$ & SA (\%) \\
\hline \multicolumn{7}{|c|}{ I. Institutional Regulations } \\
\hline s1 & $\begin{array}{l}\text { I am acquainted with the institute regulations and current } \\
\text { changes. }\end{array}$ & - & 19,0 & 9,5 & 38,1 & 33,3 \\
\hline S2 & $\begin{array}{l}\text { Sufficient information about administrative subjects is } \\
\text { provided by the institute }\end{array}$ & - & 23,8 & 28,6 & 28,6 & 19,0 \\
\hline S3 & $\begin{array}{l}\text { I know that I need to successfully pass the PhD Proficiency } \\
\text { Exam to submit my thesis proposal. }\end{array}$ & - & 9,5 & - & 23,8 & 66,7 \\
\hline S4 & $\begin{array}{l}\text { I know that in order to apply to the project grant supported by } \\
\text { DEU Department of Scientific Research Projects available } \\
\text { for PhD students, I must have presented my thesis proposal. }\end{array}$ & - & $23,8 \%$ & 4,8 & 4,8 & 66,7 \\
\hline S5 & $\begin{array}{l}\text { It is a problem for me that there isn't any institutional project } \\
\text { grants available before PhD Proficiency Exam. }\end{array}$ & - & 9,5 & 4,8 & 9,5 & 76,2 \\
\hline \multicolumn{7}{|c|}{ II. Institutional Resources } \\
\hline S6 & $\begin{array}{l}\text { Institute resources (study rooms, laboratories, technical } \\
\text { assistance, etc.) are sufficient. }\end{array}$ & 23,8 & 26,8 & 9,5 & 38,1 & - \\
\hline S7 & Project opportunities provided by my institution are sufficient. & 9,5 & 38,1 & 33,3 & 19,0 & - \\
\hline S8 & $\begin{array}{l}\text { I think that Institute provides me with adequate suggestions } \\
\text { on career planning }\end{array}$ & 33,3 & 33,3 & 19,0 & 14,3 & - \\
\hline \multicolumn{7}{|c|}{ III. DEU CoHE 100/2000 Coordination Unit } \\
\hline S9 & $\begin{array}{l}\text { It would enrich and facilitate my PhD process if the DEU } \\
\text { CoHE } 100 / 2000 \text { Coordination Unit would plan meetings } \\
\text { regularly to update all scholarship holders. }\end{array}$ & - & - & - & 28,6 & 71,4 \\
\hline S10 & $\begin{array}{l}\text { DEU CoHE 100/2000 Coordination Unit organizes frequent } \\
\text { briefing and follow-up (monitoring) meetings. }\end{array}$ & 33,3 & 23,8 & 33,3 & - & 9,5 \\
\hline S11 & $\begin{array}{l}\text { I can get in touch with DEU CoHE 100/2000 Coordination } \\
\text { Unit easily. }\end{array}$ & 14,3 & 14,3 & 28,6 & 33,9 & 9,5 \\
\hline $\mathrm{S} 12$ & $\begin{array}{l}\text { I believe that a representative should be elected in order to } \\
\text { actively communicate with GSHS and DEU CoHE 100/2000 } \\
\text { Coordination Unit on behalf of all CoHE 100/2000 } \\
\text { scholarship holders. }\end{array}$ & - & - & 19,0 & 38,1 & 42,9 \\
\hline S13 & $\begin{array}{l}\text { It is necessary that a platform is formed where CoHE } \\
100 / 2000 \text { scholarship holders can exchange information and } \\
\text { communicate. }\end{array}$ & - & - & 9,5 & 14,3 & 76,2 \\
\hline \multicolumn{7}{|c|}{ IV. Coordination of CoHE 100/2000 Scholarship Program and DEU-GSHS } \\
\hline S14 & $\begin{array}{l}\text { As an ORPHEUS student, I am glad that CoHE } 100 / 2000 \\
\text { Scholarship Program limits the PhD duration to four years. }\end{array}$ & 33,3 & 33,3 & 19,0 & 9,5 & 4,8 \\
\hline S15 & $\begin{array}{l}\text { I think that CoHE } 100 / 2000 \text { students should have the } \\
\text { flexibility to continue their studies for } 6 \text { years while getting } \\
\text { their scholarships }\end{array}$ & 4,8 & 4,8 & 4,8 & 28,6 & 57,1 \\
\hline S16 & $\begin{array}{l}\text { There is sufficient coordination between Institute Regulations } \\
\text { and CoHE } 100 / 2000 \text { Scholarship Program. }\end{array}$ & 23,8 & 28,6 & 38,1 & 9,5 & - \\
\hline S17 & $\begin{array}{l}\text { Although it's very advantageous to have a PhD with multiple } \\
\text { publications in four years while being supported by CoHE, } \\
\text { the weak compliance between mandatory rules related to } \\
\text { publication and duration and the current regulations are a } \\
\text { stress factor for me. }\end{array}$ & 4,8 & - & 14,3 & 23,8 & 57,1 \\
\hline
\end{tabular}

S: Statement, SD: strongly disagree, D: disagree, N: neutral, A: agree, SA: strongly agree, DEU: Dokuz Eylul University, GSHS: Graduate School of Health Sciences; CoHE: Council of Higher Education; ORPHEUS: Organization of Education in Biomedicine and Health Sciences in the European System 
of the students agree or strongly agree with the fact that not to be allowed to apply to the $\mathrm{PhD}$ project grant before successfully passing the proficiency exam is a problem. This is basically an institutional regulation in line with $\mathrm{CoHE}$, which allows $\mathrm{PhD}$ students to submit their thesis proposal only after successfully passing the $\mathrm{PhD}$ proficiency examinations. On the contrary, CoHE 100/2000 Scholarship Program and ORPHEUS label state that PhD students should commence on their thesis studies in the beginning of the first semesters. This conflict between the regulations is a major stress factor for PhD students since they are only funded for four years by the scholarship program. On the other hand, it is rather hard to concentrate on finding a fund and/or writing a project proposal, while taking a heavy load of classes each semester. Additionally, securing a project grant takes a long time as the two most commonly used resources when applying to a grant, TUBITAK and BAP, generally take around six to twelve months (or more, depending on the type of the grant applied) to finalize a project approval. Therefore, the students feel extremely stressed about finishing their thesis until their scholarship ends.

\section{Institutional Resources}

In this section, it was aimed to see if students' needs are met with institution's resources. There is not a mutual opinion of the students, regarding the facilities such as study rooms, laboratories, technical assistance. Though, it is understandable since the institute could not provide each department with equal resources. This situation creates an enormous imbalance between the departments and burdens both the students and the academic staff. Especially, several multidisciplinary departments such as Molecular Medicine and Translational Medicine don't have adequate laboratories, rooms for academic staff, study rooms, classrooms, meeting rooms, etc. Also, a student from a multidisciplinary department supported this idea by stating "...the infrastructure that is provided by our institute (or provided to our institute) is rather insufficient. We don't even have a laboratory...". as supported by another student's statement "...reforming the lack of infrastructure would at least diminish the difficulties we go through...". The students' opinion on the project opportunities provided by the institute is not so favorable. Probably, the considerably low budget allocated by the university for the institute is not enough to support research projects. The evaluation on the final statement of this section shows that more than $60 \%$ of the students don't think the institution's guidance on career planning is enough. Post-doctoral employment is obviously a great problem for our country. In 2018, Turkish Statistical Institute (TUIK) reported the unemployment ratio as $12,4 \%$ for higher education graduates over 15 years old (10). It is of great importance for PhD students to be aware of post-doctoral employment options and possibilities. Unfortunately, DEU GSHS lacks a professional career planning center, therefore, most students are limited to their supervisors' efforts and personal networks for career opportunities. A good guidance on career planning is highly important in established universities and should be taken into consideration as a government policy.

\section{DEU CoHE 100/2000 Coordination Unit}

Regarding the student opinion on DEU CoHE 100/2000 Coordination Unit, firstly, all participants agree or strongly agree that regular meetings should be arranged where they can convey their problems (Statement 9). Unfortunately, slightly more than half of the students disagree or strongly disagree that DEU CoHE 100/200 Coordination Unit arranges regular briefing meetings. Additionally, the answers to the statement asking the accessibility of the DEU CoHE 100/200 Coordination Unit by the students reveals that although a small percentage is happy about that, most of them have difficulty at this point. As one student states: "...Our DEU-CoHE 100/2000 Coordination Unit doesn't work actively. There is no authority/platform that updates us about our bursary program and whenever we have a problem, we cannot even find a respondent...". Another student states that "... it would help us to go through a more painless $\mathrm{PhD}$ process if the university would arrange informative meetings for CoHE 100/2000 Scholarship holders and keeps us informed on new comings of the program...". As for the solution to improve the communication issue, more than two thirds of the participants agree or strongly agree that a student representative should be elected amongst CoHE 100/2000 scholarship holders of DEU-GSHS. Almost all think that it is necessary for CoHE 100/2000 scholarship holders to have a platform to communicate. These results suggest that students expect to communicate regularly with other scholarship holders in the form of briefings and follow up meetings. Also, social media can be a tool in this equation, where an active, online group can be 
formed for discussions and sharing news, etc. DEUGSHS CoHE 100/2000 students already have a WhatsApp group to keep each other updated on changes of the program, but official meetings with authorized personnel could be more helpful.

\section{Coordination of CoHE 100/2000 Scholarship Program and DEU-GSHS}

The final section of the survey aims to find out the students' opinions on CoHE 100/2000 Scholarship Program and its coordination with DEU-GSHS regulations. We observed that more than $60 \%$ of students are not glad about the limited duration of CoHE 100/2000 Scholarship Program to four years. In parallel, most students agree or strongly agree that the bursaries should be extended if needed up to six years. In Turkey, typical PhD process takes four years although laws allow PhD students to extend this period to a maximum of 12 terms (11). However, CoHE 100/2000 Scholarship Program supports PhD students only for four years, even though the students have the right to continue their $\mathrm{PhD}$ for two more years (12). This extension can be necessary in some instances, since, as mentioned above, project evaluation and funding process might take a long time to be finalized. Thus, in the light of the survey results, we can state that the students' claim regarding to be supported by the scholarship throughout their $\mathrm{PhD}$ when they need to extend their PhD duration over four years is quite reasonable.

The answers to the last two statements in the survey put forward the students' perspective on the subject of coordination of the institutions. More than half of the students state that they are not satisfied with the coordination between DEU-GSHS and CoHE 100/2000 Scholarship Program. Also, most students agree or strongly agree that the limited duration of the bursary when combined with the publication requirements of ORPHEUS is stressful for them. On one hand, since CoHE 100/2000 Scholarship Program is a rather new program, some aspects of the program are not fully established yet. As one student states; "I think that regulations are insufficient in many ways, containing important gaps and contradictions. For example, nothing is written anywhere about maternity leave, and the terms are not clear about our rights on suspending our studies...". On the other hand, since, DEU-GSHS has recently met the ORPHEUS regulations following to be awarded with the ORPHEUS label, DEU-GSHS has still been working on the harmonization of
ORPHEUS regulations with the previous education system. Now, DEU-GSHS has a novel burden to consider the regulations for the $\mathrm{PhD}$ students who are supported with CoHE 100/2000 Scholarship. Supporting this idea, one student states "...Changing our institute's regulations according to the ORPHEUS and CoHE 100/2000 Scholarship Program ... would at least diminish the difficulties we go through...". This comment and the results of the survey support our previous hypothesis that all these factors contribute to the stressful nature of the $\mathrm{PhD}$ period as perceived by the students. Therefore, we believe that coordination is of great importance concerning CoHE $100 / 2000$ scholars and institutes, especially the ones with ORPHEUS label, and this problem should be tackled by all concerning institutions as swiftly as possible.

\section{CONCLUSION}

Although this article only explores the problems of the CoHE 100/2000 scholarship holders of DEU-GSHS, and is limited to the number of students enrolled at the time of the study. Scholars from different institutes or universities are likely to be facing different issues as well as the ones mentioned in this article. Therefore, reaching out to more CoHE 100/2000 students is necessary in order to understand the problems and the needs of CoHE 100/2000 scholarship holders all over Turkey.

Results of this research presented in this paper demonstrates several fundamental problems of the CoHE 100/2000 Scholarship holders of DEU-GSHS. We list below those problems and some suggestions as possible solutions:

Most students are not fully informed about all regulations and necessities of ORPHEUS, CoHE 100/2000 Scholarship Program and DEU-GSHS. We believe that this survey also motivated some of the students to learn more about these institutional regulations, however, students seem to be in need of a clear guide on said regulations.

There is a major conflict on presentation of the $\mathrm{PhD}$ thesis proposal between ORPHEUS, CoHE 100/2000 Scholarship Program and DEU-GSHS regulations. Since DEU-GSHS regulations are determined in line with $\mathrm{CoHE}$ regulations, this conflict can only be sorted out by CoHE itself.

DEU-GSHS PhD graduates lack a professional career counselling opportunity. We believe universities in collaboration with COHE should arrange meetings to guide not only CoHE 100/2000 
Scholarship holders, but also all $\mathrm{PhD}$ graduates where they can make new connections and introduce themselves to new circles.

Even though DEU has established a CoHE 100/2000 Coordination Unit, this unit does not meet the students' needs. They want regular meetings where they are informed about current status of the program and they can meet new students going through a similar process to share experiences with. To fix this, optional monthly meetings can be arranged, where a student representative is elected to convey any problems students may encounter to the authorities. Election of student representatives and establishing a problem-solving team in each university would provide an opportunity to observe and acknowledge some of these conflicts and find solutions if possible. Additionally, meetings can be arranged with CoHE $100 / 2000$ scholars from all over Turkey to share the students' experiences and needs.

There is an overall conflict between regulations of ORPHEUS, CoHE 100/2000 Scholarship Program and DEU-GSHS. However, only a selected number of universities in Turkey has been awarded with the ORPHEUS label, hence, these universities may require different solutions depending on their individual regulations.

Students are mostly stressed about extending their studies after their bursary is halted. Since most PhD processes are extended over four years because of the duration a research project proposal is resulted, providing the help of project offices on project writing could help students cope with this problem. Also, providing the flexibility to extend the scholarship with specific demands could be helpful for students.

In conclusion, this survey-based research reveals the urgent need of harmonizing the regulations of all the associated institutions involved in the $\mathrm{PhD}$ process of CoHE 100/2000 scholars. This study only presents the problems and needs of the CoHE 100/2000 Scholarship holders of DEU-GSHS, and is limited to the number of students enrolled at the time of the study. Scholars from different institutes or universities are likely to be facing different issues as well as the ones mentioned in this article. Therefore, reaching out to more CoHE 100/2000 students is necessary in order to understand the problems and the needs of CoHE 100/2000 scholarship holders all over Turkey.

Conflict of Interest: The authors declare no competing financial interests and no conflict of interest.

Peer-review: Externally peer-reviewed.

\section{REFERENCES}

1. Council of Higher Education, Turkey (April, 1. Council of Higher Education. YÖK 100/2000 Doktora Bursları Broşürü. Turkey, 2018.

2. Council of Higher Education. 100/2000 YÖK Doktora Bursları Kitapçığı. Turkey, 2018.

3. Council of Higher Education. YÖK Bursuyla 3 Binin Üzerinde Doktorali İnsan Kaynaği Yetişiyor, 2018 November (cited 2019). Available from: URL: https://www.yok.gov.tr/Sayfalar/Haberler/yokburslari-ile-3-binin-uzerinde-insan-kaynagiyetisiyor.aspx

4. CoHE $100 / 2000$ PhD Scholarships. YÖK 100/2000 Projesi- Doktora Burs Programının 4. Çağrı Döneminde Desteklenen Üniversiteler ve Alanları Belli Oldu, 2018 September (cited 2020). Available from:

URL: https://yuzikibinbursu.yok.gov.tr/Sayfalar/Haber DuyuruDetay. aspx?did=1

5. Council of Higher Education. YÖK 100/2000 Öğrenci Buluşmalarinin Dördüncüsü İstanbul'da Düzenlendi, October 2019 (cited 2020). Available from:

URL: https://www.yok.gov.tr/Sayfalar/Haberler/2019/yo k-100-2000-ogrenci-bulusmalari-istanbul.aspx

6. Organisation for PhD Education in Biomedicine and Health Sciences in the European System. Mission Statement, 2013 (cited 2020). Available from: URL: $\quad$ http://www.orpheusmed.org/index.php/about-us/orpheus-missionstatement

7. Organisation for PhD Education in Biomedicine and Health Sciences in the European System. Standards for $\mathrm{PhD}$ Educationin Biomedicine and Health Sciences in Europe, 2012 (cited 2020). Available from: URL: http://www.orpheusmed.org/images/stories/documents/ORPHEUSAMSE-WFME_tur.pdf

8. Dokuz Eylül University Graduate School of Health Sciences. Doktora Başvuru Kayıt Eğitim Süreci, 2018 (cited 2020). Available from: URL: http://saglikbil.deu.edu.tr/tr/doktora-basvuru-kayitegitim-sureci/

9. Dokuz Eylül University Department of Scientific Research Projects. Özgelirler ile Desteklenen Projeler (cited 2020). Available from: URL: http://bap.deu.edu.tr/tr/projeler/ozgelirler-iledesteklenen-projeler/

10. Türkiye İstatistik Kurumu Merkezi Dağıtım Sistemi. İsgücü İstatistikleri (cited 2020). Available from: 
URL:

https://biruni.tuik.gov.tr/medas/?kn=72\&locale $=\mathrm{tr}$

11. T.C. Resmi Gazete. Yönetmelik, July 2018 (cited 2020). Available from: URL:https://www.resmigazete.gov.tr/eskiler/2018/ 07/20180722.pdf

12. Council of Higher Education. Yükseköğretim Kurulu Tarafindan Doktora Programlarina Kayitli Öğrencilere Verilecek Burslara Ilişkin Usul Ve Esaslar, January 2018 (cited 2020). Available from:

URL:

https://www.yok.gov.tr/Documents/Ogrenci/BursD okuman/100_2000_Doktora_bursu_Usul_ve_

Esaslar.pdf 